\title{
3. IPOD SURVEY AREA AT-6: A SITE SURVEY1
}

\author{
G. M. Purdy, Hans Schouten, and John Crowe ${ }^{2}$, Woods Hole Oceanographic Institution, Woods Hole, \\ Massachusetts \\ D. L. Barrett and R. K. H. Falconer, Atlantic Geoscience Centre, Bedford Institute, Halifax, Nova Scotia \\ and \\ G. B. Udintsev ${ }^{3}$, N. A. Marova, V. M. Litvin, G. M. Valyashko, V. M. Markushevich3, and V. V. \\ Zdorovenin ${ }^{3}$, Institute of Oceanology, Academy of Sciences of the U.S.S.R \\ Moscow, U.S.S.R.
}

\section{INTRODUCTION}

IPOD Survey Area AT-6 is located near anomaly 5, between latitudes $22^{\circ} \mathrm{N}$ and $23^{\circ} \mathrm{N}$, about $140 \mathrm{~km}$ east of the median valley of the Mid-Atlantic Ridge and 50 $\mathrm{km}$ south of the Kane fracture zone. The site survey data were collected within an approximate one degree square by the Woods Hole research vessel Atlantis II and the Akademik Kurchatov of the U.S.S.R. The suggested drill site was the sediment pond at $22^{\circ} 58^{\prime} \mathrm{N}$, $43^{\circ} 31^{\prime} \mathrm{W}$ : this recommendation was based on bathymetry, airgun seismic reflection, and magnetics data.

\section{DATA}

The resolution and accuracy of the bathymetry contour charts shown in Figures 1 and 2 are limited by the use of conventional $12-\mathrm{kHz}$ and $3.5-\mathrm{kHz}$ echo sounders over such precipitous topography. Navigation was by satellite, supplemented in the detailed survey area by three 15-n.mi. range moored radar transponder buoys, positioned as shown in Figure 2. The locations of piston cores and heat flow' measurements are also shown in Figure 2. A standard Ewing-type heat-flow instrument was used, with outrigger probes mounted on piston core barrels and a water temperature probe attached to the corehead. Thermal conductivity was determined using the needle probe method described by Von Herzen and Maxwell (1959). A conventional $300-$ in $^{3}$ airgun seismic reflection system was used, and seismic refraction data were collected using $73 \mathrm{MHz}$ radiosonobuoys and the Lamont-type ocean-bottom seismometer system. The gravity meter system was the vibrating string accelerometer type described by Bowin et al., 1972. The free-air gravity anomalies were calculated using the International Gravity Formula (1967) and the International Gravity Standardization Net of 1971. The international Geomagnetic Reference Field of 1975 was used to compute the magnetic anomalies.

\section{SITE DESCRIPTION}

The bathymetry contour chart (Figure 1) shows rugged topography typical of the Mid-Atlantic Ridge

\footnotetext{
${ }^{1}$ W.H.O.I. Contribution No. 3976.

2 Also at Department of Earth and Palentary Sciences, Massachusetts Institute of Technology, Cambridge, Massachusetts.

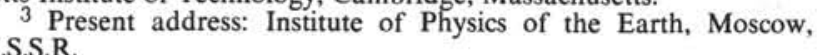

flank province. Maximum relief is 1600 meters, and the major troughs reach 4400 to 4500 meters in depth. A significant feature is the predominant linear northsouth trend of the major ridges and troughs. At approximately longitude $43^{\circ} 37^{\prime} \mathrm{W}$, a scarp 400 to 700 meters high extends north-south across the survey area. It suffers a lateral dislocation at latitude $22^{\circ} 40^{\prime} \mathrm{N}$, but otherwise is continuous for a distance of at least 30 n.mi. To the east of this major feature there is a 4-to 5-n.mi.-wide band of subdued topography (4100-4400 m) which we have called Five Trough. The eastern boundary of this trough is not well defined and is nowhere as steep and continuous as the scarp to the west. Attempts at dredging this western scarp proved unsuccessful.

Two sediment ponds of significant extent (approximately $11 \times 3 \mathrm{~km})$ and with sediment thicknesses $>100 \mathrm{msec}$ (two-way travel time) exist within Five Trough (shaded areas in Figure 2): piston cores were taken in both (Table 1 and Figure 2). The deep drill Site 396 was situated in the southernmost of these two ponds. This drill site pond is surrounded on all sides by small-scale hummocky topography. The Five Trough scarp is 5 to $6 \mathrm{~km}$ to the west and is at its steepest and highest $(\sim 1 \mathrm{~km})$ at this point. The height of the scarp is increased here by a small ( $8 \mathrm{~km}$ long, $2-3 \mathrm{~km}$ wide) ridge, 200 to 300 meters high and striking north-south, situated atop the main scarp. The north-south limits of this ridge are approximately those of the drill site pond. Figure 3 shows one of the nine seismic reflection profile crossings of the drill site pond. Resolution is poor because of the low frequency source characteristics of the 300- $\mathrm{in}^{3}$. airgun and the side echoes and hyperbolae caused by the rough basement. Maximum sediment thickness within this pond varies between 200 and $250 \mathrm{msec}$; the thicker sediments lie toward the eastern edge.

Table 1 summarizes the data for piston cores taken within the two major sediment ponds of Five Trough. Stations 19 and 27 were situated in the drill site pond. Each of the cores contains sediment consisting of calcareous ooze and short intervals of coarse foraminifer sand. The sand layers are commonly graded, and have sharp lower contacts. Nannofossils are abundant and well preserved in all intervals of the cores, whereas foraminifers are most abundant $(>10 \%)$ in graded units. The presence of discoasters in trace amounts throughout the length of all three cores indicates 


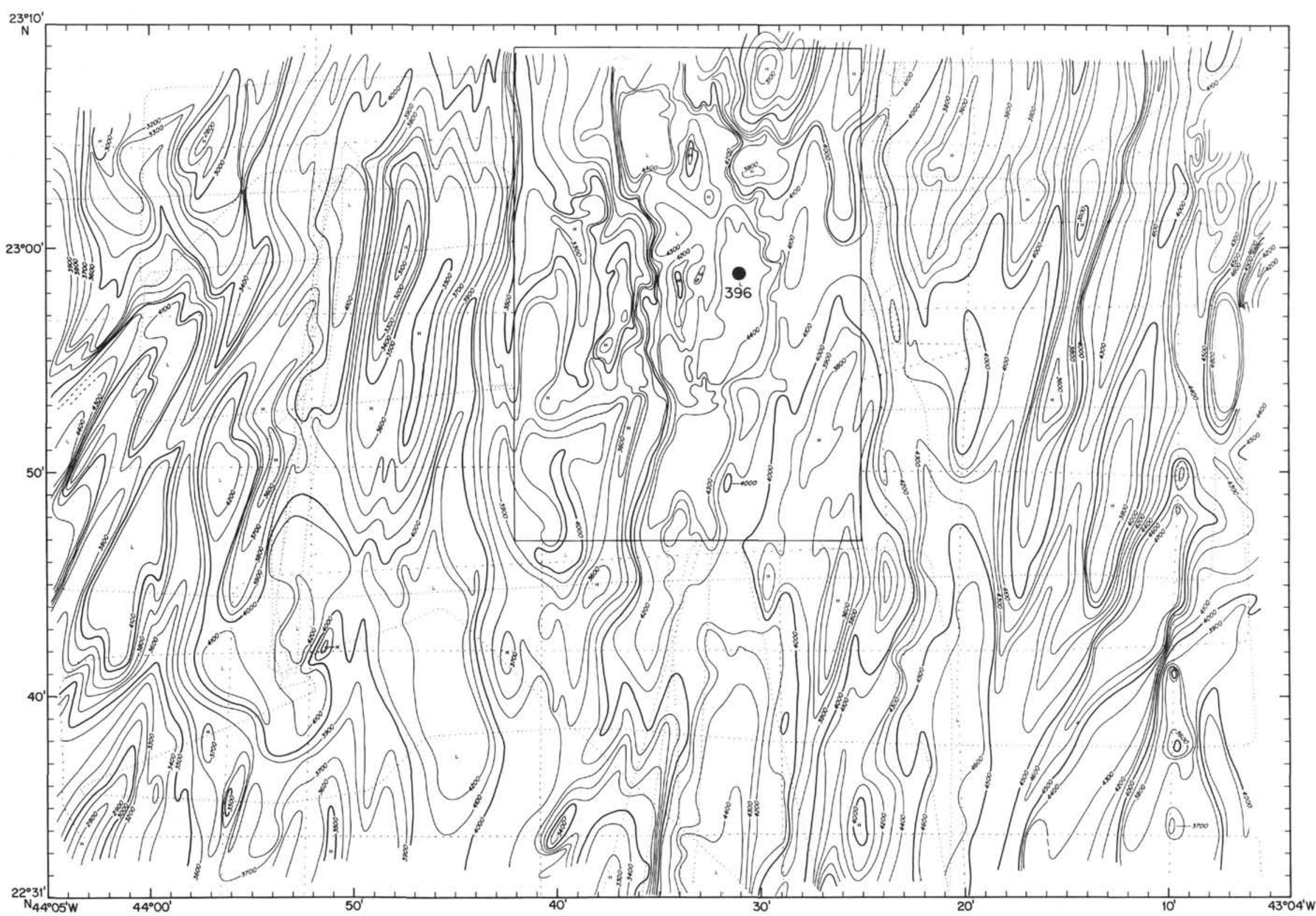

Figure 1. Bathymetry of the site survey area. Contour interval is 100 corrected meters. Location of Site 396 is shown. Box encloses detailed survey area shown in Figure 2. 


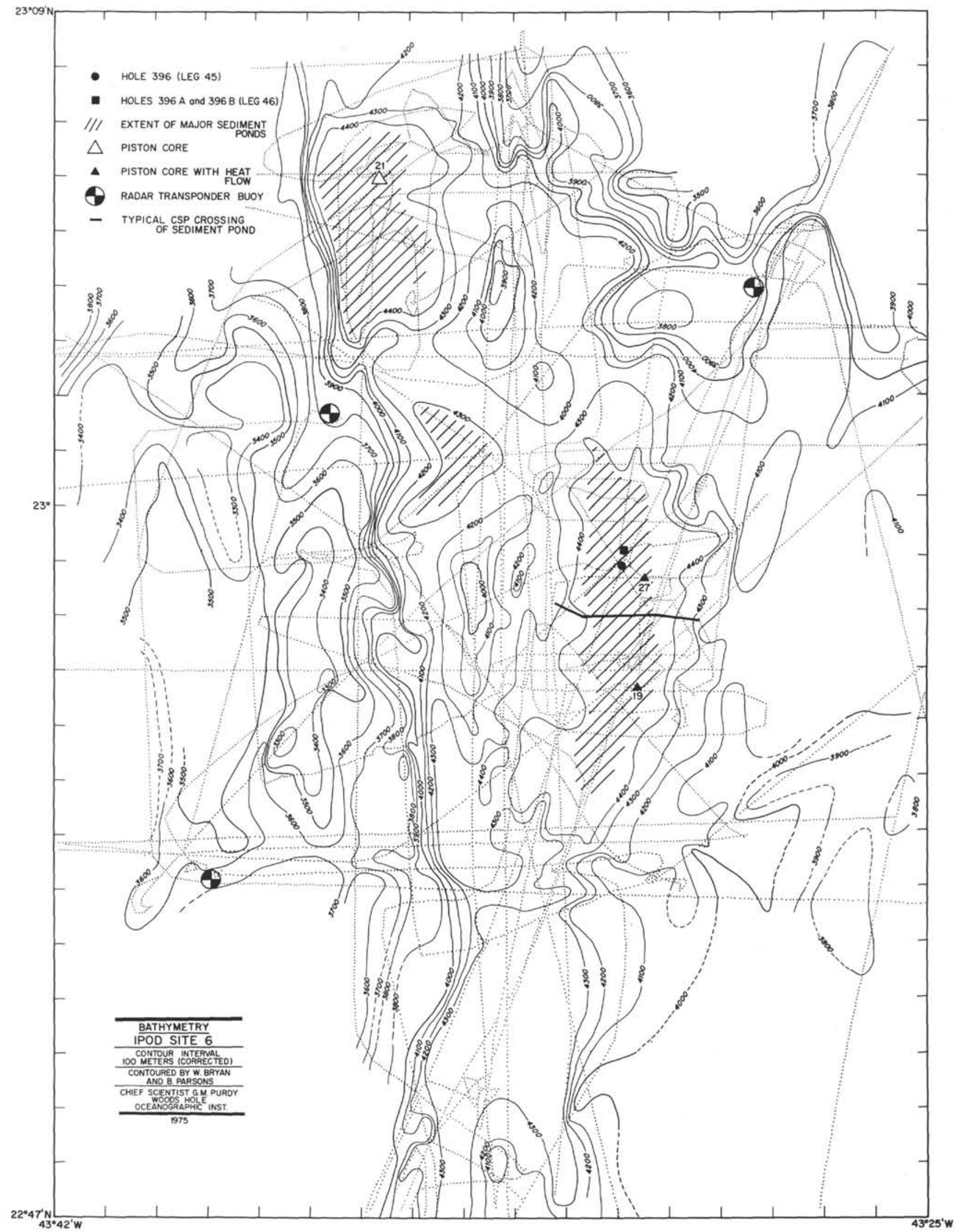

Figure 2. Bathymetry of the detailed survey area. Contour interval is 100 corrected meters. Location of Holes 396, 396A, and 396B, piston cores, and heat flow measurements are shown. The original record of the "typical"continuous seismic profile is shown in Figure 3. 
TABLE 1

Piston Cores in the Two Major Sediment Ponds of Five Trough (see Figure 2)

\begin{tabular}{ccccc}
\hline Station & Latitude & Longitude & $\begin{array}{c}\text { Core Length } \\
(\mathrm{cm})\end{array}$ & $\begin{array}{c}\text { Water Depth } \\
(\mathrm{m})\end{array}$ \\
\hline 19 & $22^{\circ} 55.5^{\prime} \mathrm{N}$ & $43^{\circ} 30.6^{\prime} \mathrm{W}$ & 516 & 4448 \\
21 & $23^{\circ} 05.8^{\prime} \mathrm{N}$ & $43^{\circ} 36.7^{\prime} \mathrm{W}$ & 526 & 4422 \\
27 & $22^{\circ} 58.7^{\prime} \mathrm{N}$ & $43^{\circ} 30.6^{\prime} \mathrm{W}$ & 636 & 4431 \\
\hline
\end{tabular}

reworking; there is no evidence that any of the cores penetrated into pre-Pleistocene sediments. Hemipelagic clay is common in all cores. Biogenic silica, pteropods, detrital mineral grains, volcanic shards, and zeolites are absent. Manganese micronodules are present in trace amounts.

The lithology of the three cores suggests a depositional environment dominated by pelagic sedimentation of calcareous microfossils and hemipelagic clay. The site is apparently near or just below the foraminifer lysocline, since abundance of foraminifers is low except in the graded units. The presence of graded units, together with pre-Pleistocene components (discoasters) throughout the cores, indicates reworking of sediment into these ponds from nearby topographic highs. Such reworking may have been either under the influence of slow steady bottom currents, or as episodic events comparable to turbidity currents (e.g., van Andel and Komar, 1969).

The two successful heat flow measurements taken in the drill site sediment pond indicate very low heat flow (less than one HFU); this is typical of such measurements in sedimentary environments where hydrothermal activity is believed to exist. The temperature versus depth profiles and conductivity versus depth results are presented in Figures 4a and 4b. A heat flux of 0.27 HFU was calculated for Station 27. It appears that Station 19 was disturbed by an unknown cause (related to hydrothermal activity?) possibly preventing the outrigger thermistors from reaching thermal equilibrium with the surrounding sediments. As a result it is difficult to assign a credible heat flux to this station; these complications do not obscure the fact, however, that the heat flux is less than $0.7 \mathrm{HFU}$. At both stations bottom water temperatures ( Tw) of $2.52^{\circ} \mathrm{C}$ were recorded. Other data pertaining to these stations are listed in Table 2.

The heat flux measured at both stations is extremely low. Thermal models of oceanic lithosphere predict heat flow as a function of age equivalent to $\mathrm{HF}=12$ / $V \mathrm{t}$, where $t$ is in millions of years. This site is on crust of the age of anomaly 5, i.e., about 10 m.y. (Talwani et al., 1971). Therefore a large difference exists between the heat flow predicted for the site (4 HFU) and that actually measured. This phenomenon has been observed in similar surveys conducted near ridge crests (Lister, 1972; Sclater et al., 1974), and has been attributed to the mass transport of heat by hydrothermal circulation within a "permeable" oceanic crust. Figure 5 illustrates possible convection flow patterns

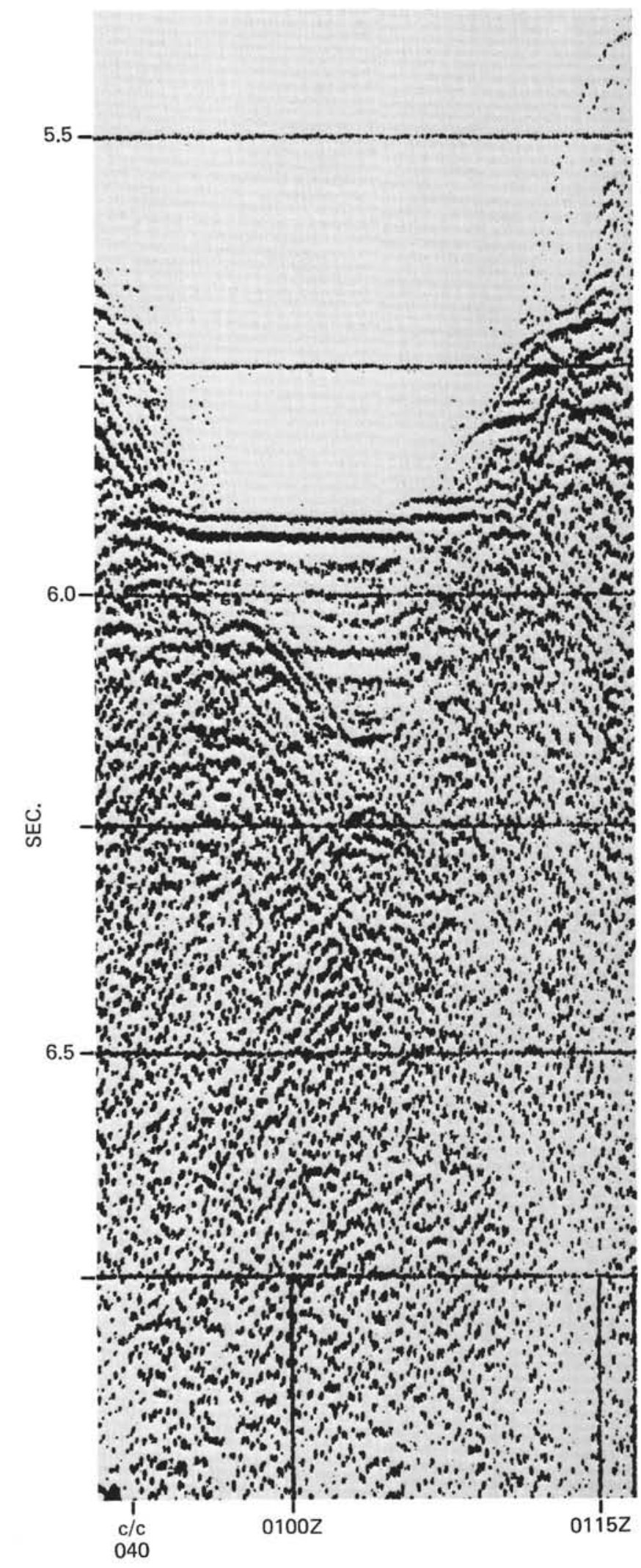

Figure 3. Original record of one of the nine airgun seismic reflection profiles crossing the drill site sediment pond. Location is shown in Figure 2. West is to the left. 

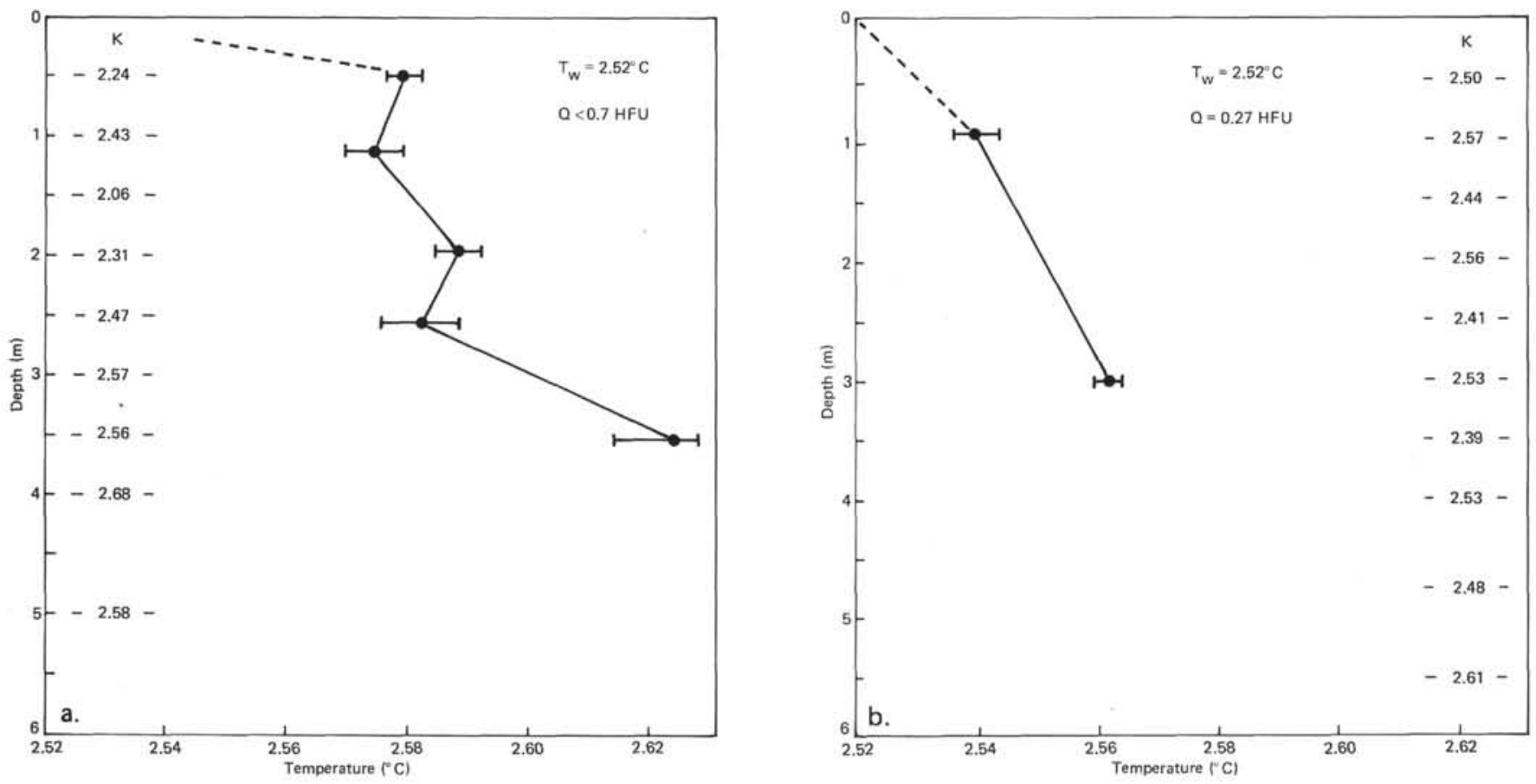

Figure 4. Profiles of sediment temperature vs depth and listing of thermal conductivity (units of $10^{-3} \mathrm{cal} / \mathrm{cm}$-sec- ${ }^{\circ} \mathrm{C}$ ) versus depth for (a) Station 19 and (b) Station 27. $T_{w}=$ bottom water temperature, $Q=$ calculated heat flow in units of HFU (one $\mathrm{HFU}=10^{-6} \mathrm{cal} / \mathrm{cm}^{2}$-sec).

TABLE 2

Heat Flow Data

\begin{tabular}{cccccccccc}
\hline Station & Latitude & Longitude & $\begin{array}{c}\text { Water Depth } \\
(\mathrm{m})\end{array}$ & $\begin{array}{c}\mathrm{Tw} \\
\left({ }^{\circ} \mathrm{C}\right)\end{array}$ & $\begin{array}{c}d \mathrm{~T} / d z \\
\left({ }^{\circ} \mathrm{C} / \mathrm{cm}\right)\end{array}$ & $K^{\mathrm{a}}$ & $Q^{\mathrm{b}}$ & $\begin{array}{c}\text { Angle }^{\mathrm{c}} \\
(\text { degrees })\end{array}$ & $\begin{array}{c}\text { Pen }^{\mathrm{d}} \\
(\mathrm{cm})\end{array}$ \\
\hline 19 & $22^{\circ} 55.5^{\prime} \mathrm{N}$ & $43^{\circ} 30.6^{\prime} \mathrm{W}$ & 4448 & 2.52 & 0.297 & 2.38 & $<0.7$ & $<15$ & 352 \\
27 & $22^{\circ} 58.7^{\prime} \mathrm{N}$ & $43^{\circ} 30.6^{\prime} \mathrm{W}$ & 4431 & 2.52 & 0.107 & 2.50 & 0.27 & $<15$ & 301 \\
\hline
\end{tabular}

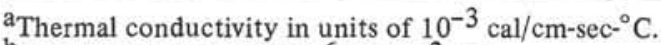

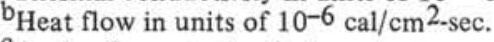

${ }^{c}$ Angle of penetration in degrees measured from vertical.

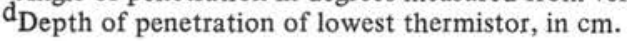

within the basement along an east-west cross-section of the drill site at $22^{\circ} 57^{\prime} \mathrm{N}$ from $43^{\circ} 20^{\prime} \mathrm{W}$ to $43^{\circ} 40^{\prime} \mathrm{W}$. It appears that over $3 \mathrm{HFU}$ is being lost by hydrothermal circulation, if the total theoretical heat budget is to be balanced.

The free-air gravity anomaly contour chart (Figure 6 ) shows the gravity field to vary between -20 and $+30 \mathrm{mgl}$ over the survey area. The predominant trends are those of the topography, but it does more clearly indicate that Five Trough has a segmented structure; small left lateral offsets of its associated gravity low occur at about latitudes $23^{\circ} 03^{\prime} \mathrm{N}$ and $22^{\circ} 43^{\prime} \mathrm{N}$.

Eight magnetic anomaly profiles crossing the survey area are shown in Figure 7a (for track locations see Figure 8). To remove the skewing effect of non-vertical magnetization vectors, the linear filtering technique of phase-shifting anomalies was applied (Schouten and McCamy, 1972). The skewness parameter used was $60^{\circ}$. The phase-shifted anomalies are shown in Figure $7 \mathrm{~b}$. Three correlatable linear anomalies are evident; we identify them as anomalies $4,4^{\prime}$, and 5 (Purdy et al., this volume). Anomaly 4 is clearly defined on all tracks; anomaly $4^{\prime}$ is clear only north of track R4. Although anomaly 5 is seen everywhere, there is a noticeable change in character at about latitude $22^{\circ} 45^{\prime} \mathrm{N}$, i.e., at profile R6; this corresponds approximately to the location of the left lateral offset of the gravity low and topography associated with Five Trough, shown in Figure 6. To the south of track R6, anomaly 5 is a distinctive narrow peak, but to the north it is much broader and less well defined.

Figure 7c shows the calculated magnetization distributions along these eight tracks, from simple linear inversions of the observed anomalies. These calculations take no account of topography; we assume that the anomalies are attributable only to variations in magnetization within a semi-infinite $0.5-\mathrm{km}$-thick crustal slab situated $4 \mathrm{~km}$ below sea level.

The calculated magnetization distributions shown in Figure $7 \mathrm{c}$ have been simplified into their principal positively and negatively magnetized components, and 


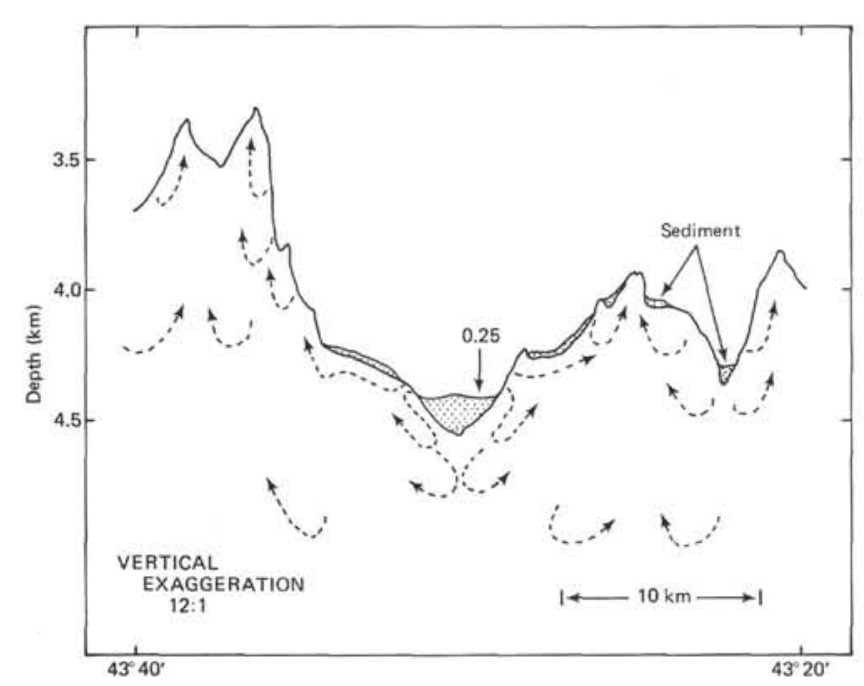

Figure 5. Possible convection flow patterns within the basement along an east-west cross-section of IPOD Site 6 at $22^{\circ} 57^{\prime} \mathrm{N}$ from $43^{\circ} 20^{\prime} \mathrm{N}$ to $43^{\circ} 40^{\prime} \mathrm{W}$.

locations of the major positively magnetized units plotted on the bathymetry contour chart, as shown in Figure 8. This provides a grossly simplified but convenient display to aid in the choice of drill site. The magnetic reversal time scale of Talwani et al. (1971) is also shown in this figure for comparison: a halfspreading rate of $20 \mathrm{~mm} /$ year is assumed. Figure 8 shows that the crustal body causing anomaly 5 underlies Five Trough everywhere (hence the name). The simplifying assumptions made in these calculations allow little or no significance to be placed on the small (4-5 km) offsets of the crustal "bodies" from track to track (which are rarely spaced more than 6 or $7 \mathrm{~km}$ apart). Tracks AII3/AII4, R7, and AII5 show that the drill site sediment pond is underlain by "anomaly 5 crust." These three tracks define a "rectangle" of anomaly 5 crust offset 4 to $5 \mathrm{~km}$ to the west of the general trend of anomaly 5 . No such offset is evident in either anomaly $4^{\prime}$ or 4 . The north-south extent of this apparently offset body corresponds to that of the ridge which causes the western scarp of Five Trough west of the drill site sediment pond to be unusually high (about $1 \mathrm{~km}$ ). It is attractive to speculate that this coincidence is a consequence of a lava emplacement process which is highly variable in both rate and volume along the length of the ridge axis. No fracture zones of offset large enough to be resolved by these data were detected within the survey area. It must be noted that the work of Blakely (1974) suggests that anomaly 5 was caused not by a single normal event about $1 \mathrm{~m}$.y. long (as it is represented in Figure 8), but by a set of five normal events separated by short (10,000-100,000-year) reversals.

The seismic refraction results are discussed in Barrett and Purdy (this volume). Three reversed lines were carried out using Lamont-type ocean bottom seismometers (Carmichael et al., 1973) and radio telemetering sonobuoys. One of these experiments was located along
Five Trough and yielded normal oceanic crustal velocities and thicknesses (Figure 9). The limited resolving power of conventional refraction experiments, which rely on the propagation of seismic energy of wavelengths of about 500 meters, means that significant comparison between the layering determined by drilling and that determined from these experiments is not possible.

\section{CONCLUSIONS}

These geophysical data collected during the site survey effort show that Site 396 is on oceanic crust, 9 to 10 m.y. old, formed during the magnetic anomaly 5 period. No evidence was found for the existence of fracture zones of significant offset close to the drill site. These data do not have the resolution to predict, on a small scale, the magnetic polarity of the basalt lavas lying beneath the drill site sediment pond. Although anomaly 5 is characterized mostly by a normal event about $1 \mathrm{~m} . y$. long, the probable temporally and spatially random processes of lava emplacement in the median valley, and the short reversed intervals during the anomaly 5 period, suggested by Blakely (1974), mean that recovery of both normal and reversed samples is not unexpected.

\section{ACKNOWLEDGMENTS}

We thank the officers, crew, and scientific parties on board the research vessels Atlantis II and Akademik Kurchatov for their help and cooperation in collecting these data. David A. Johnson provided the interpretation of the core samples. W. B. Bryan and B. Parsons contoured the bathymetry data. This work was supported by a contract to IPOD Site Survey Management.

\section{REFERENCES}

Blakely, R. J., 1974. Geomagnetic reversals and crustal spreading rates during the Miocene, J. Geophys. Res., v. 79 , p. 2979.

Bowin, C. O., Aldrich, T. C., and Folinsbee, R. A., 1972. VSA Gravity Meter System: tests and recent developments, J. Geophys. Res., v. 77, p. 2018.

Carmichael, D., Carpenter, G., Hubbard, A., McCamy, K., and McDonald, W., 1973. A recording ocean bottom seismograph, J. Geophys. Res., v. 78, p. 8748

Lister, C. R. B., 1972. On the thermal balance of a mid-ocean ridge, Geophys. J. Roy. Astron. Soc., v. 26, p. 515.

Schouten, H. and McCamy, K., 1972. Filtering marine magnetic anomalies, J. Geophys. Res., v. 77, p. 7089.

Sclater, J. G., Von Herzen, R. P., Williams, D. L., Anderson, R. N. and Klitgord, K., 1974. The Galapagos spreading center: heat flow low on the North Flank, Geophys. J. Roy. Astron. Soc., v. 38, p. 609.

Talwani, M., Windisch, C. C., and Langseth, M. G., 1971. Reykjanes Ridge Crest: a detailed geophysical study, $J$. Geophys. Res. v. 76, p. 473.

van Andel, Tj. H. and Komar, P. D., 1969. Ponded sediments of the Mid-Atlantic Ridge between $22^{\circ}$ and $23^{\circ}$ North latitude, Geol. Soc. Am. Bull., v. 80, p. 1163.

Von Herzen, R. P. and Maxwell, A. E., 1959. The measurement of deep sea sediments by a needle-probe method, $J$. Geophys. Res., 


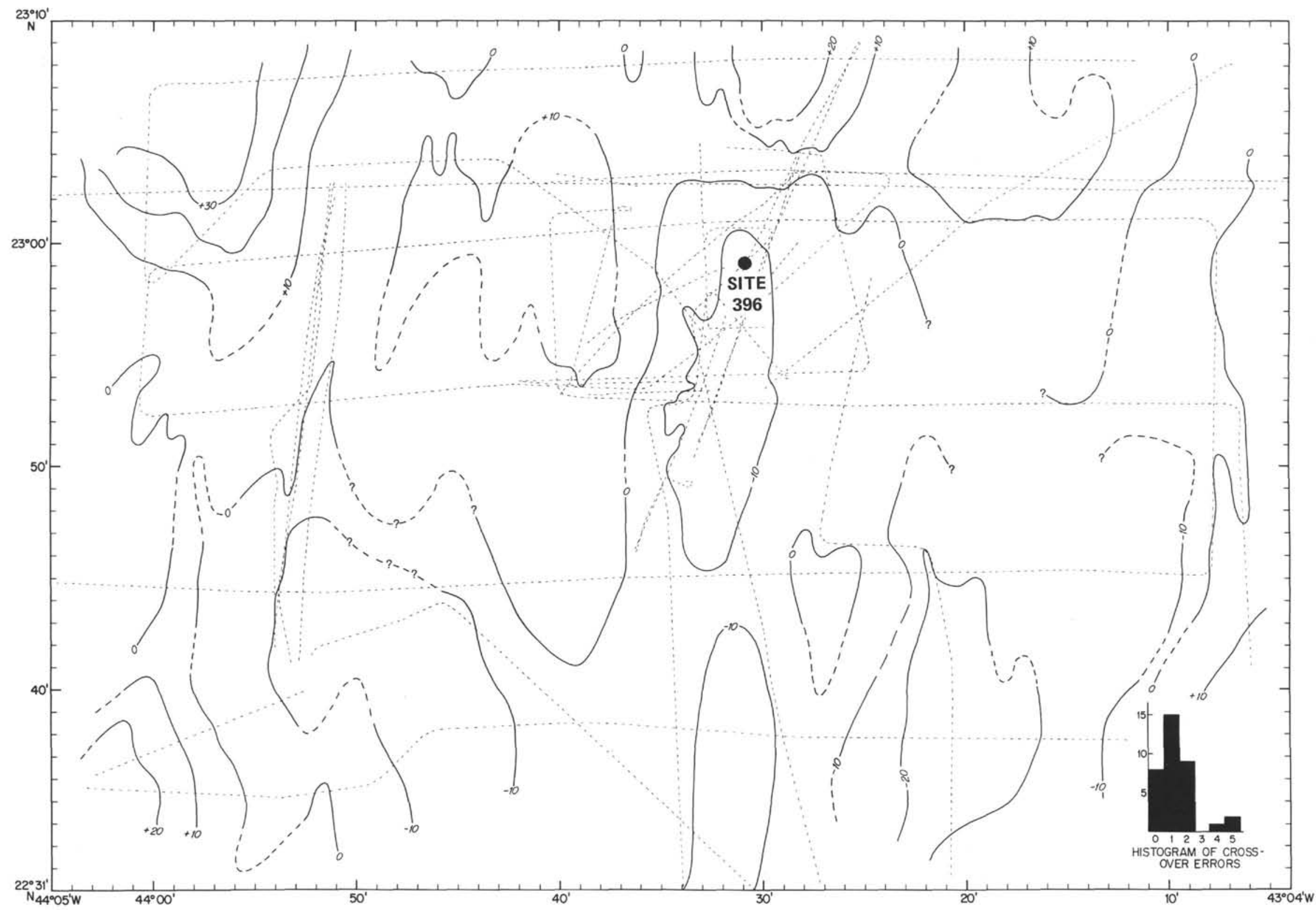




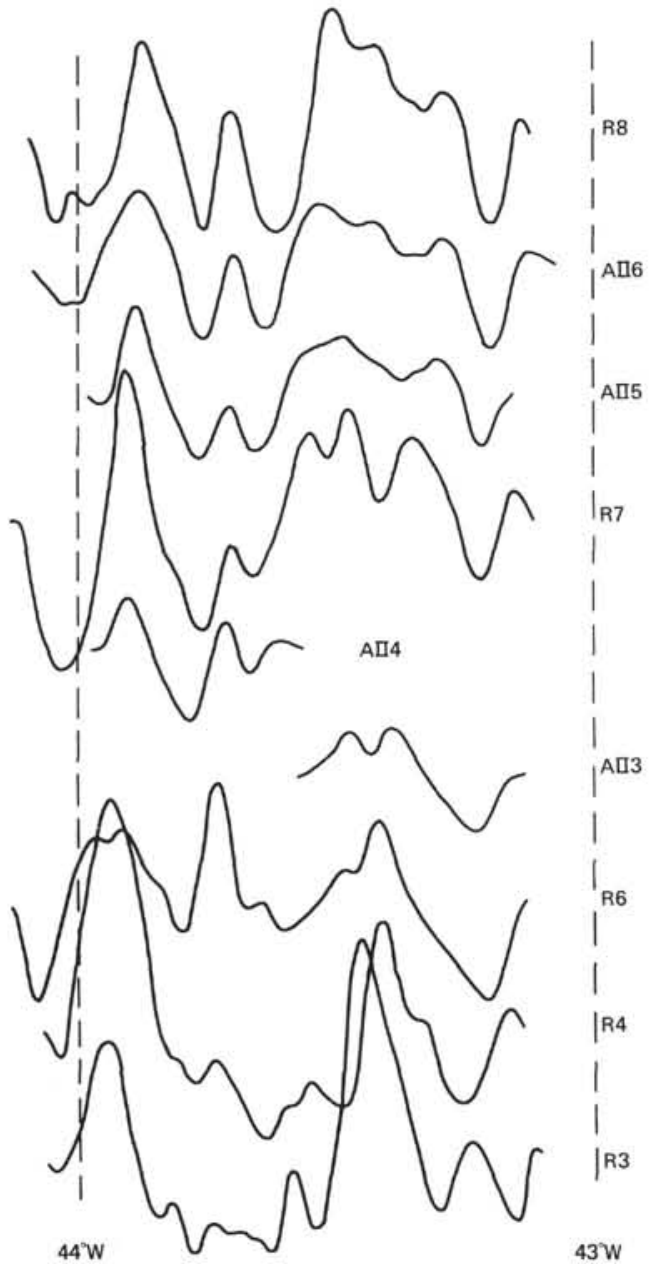

(a)

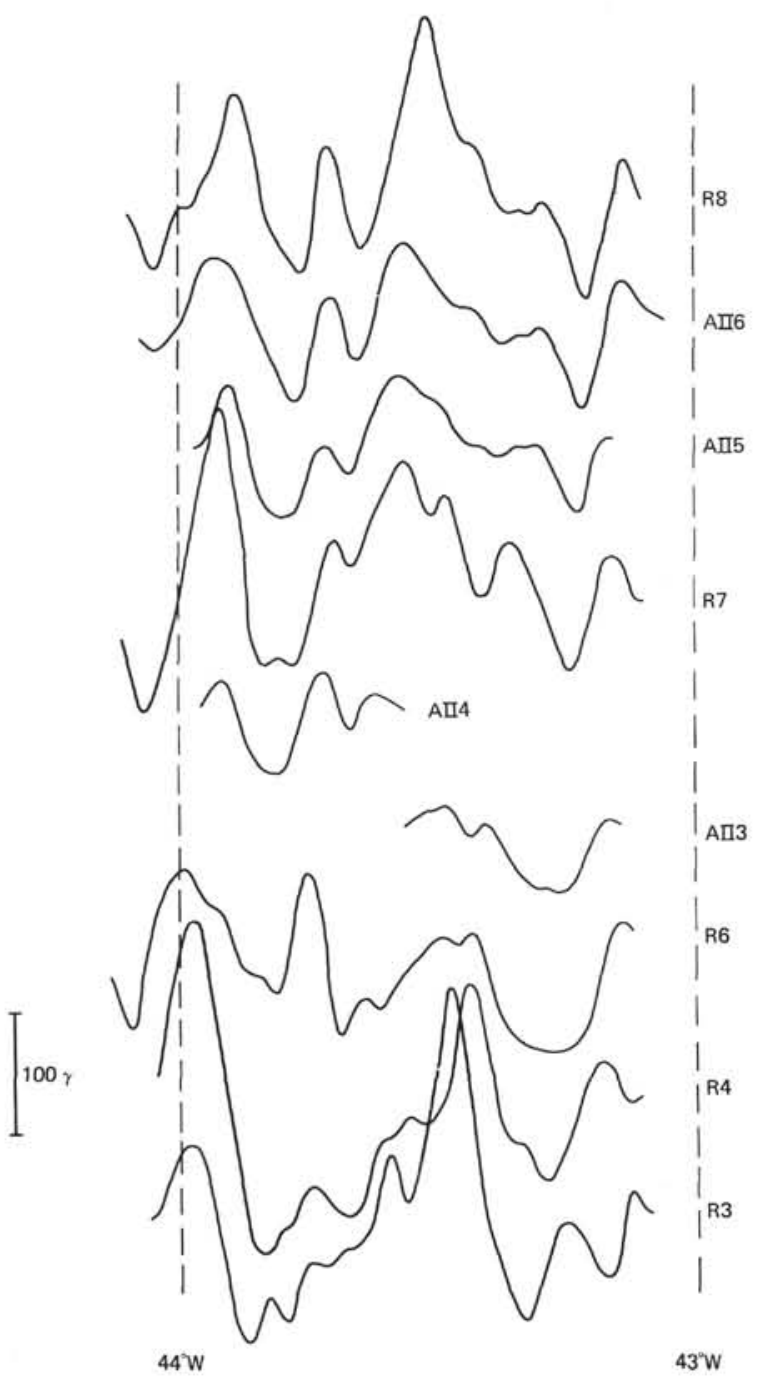

(b)

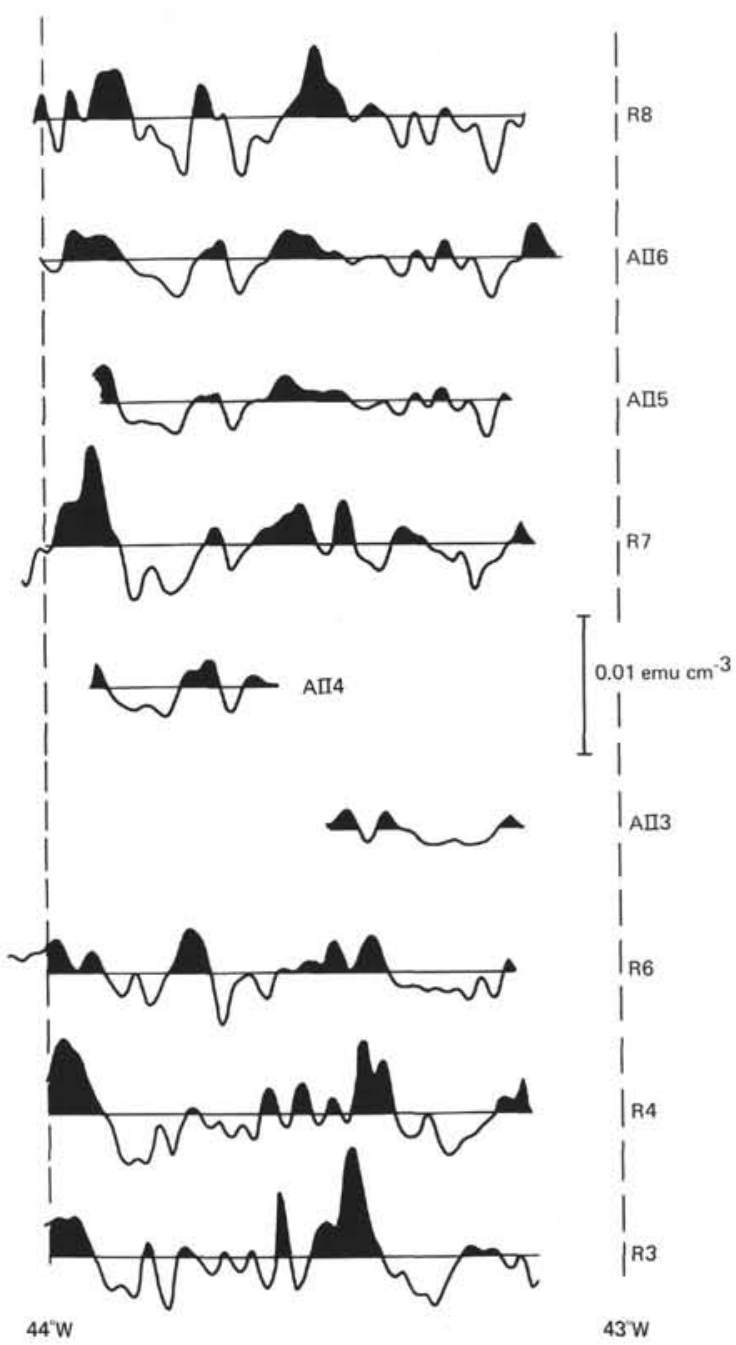

(c)

Figure 7. (a) Observed magnetic anomaly profiles crossing the survey area. Track locations are shown in Figure 8. Prefix $R$ denotes Akademik Kurchatov data; prefix Ax denotes $R / V$ Atlantis II data. Anomalies $4,4^{\prime}$, and 5 are identified at approximately longitudes $43^{\circ} 52^{\prime} \mathrm{W}, 43^{\circ} 42^{\prime} \mathrm{W}$ and $43^{\circ} 25^{\prime} \mathrm{W}$, respectively. (b) The magusic anomalies shown in Figure 7 (a), but phase-shifted following the technique of Schouten and McCamy (1972). The skewness parameter used was $60^{\circ}$. (c) Calculated magnetization distributions from simple linear inversions of the observed anomalies. It was assumed that the anomalies were caused by a 0.5-km-thick semiinfinite slab situated $4.0 \mathrm{~km}$ below sea level. 


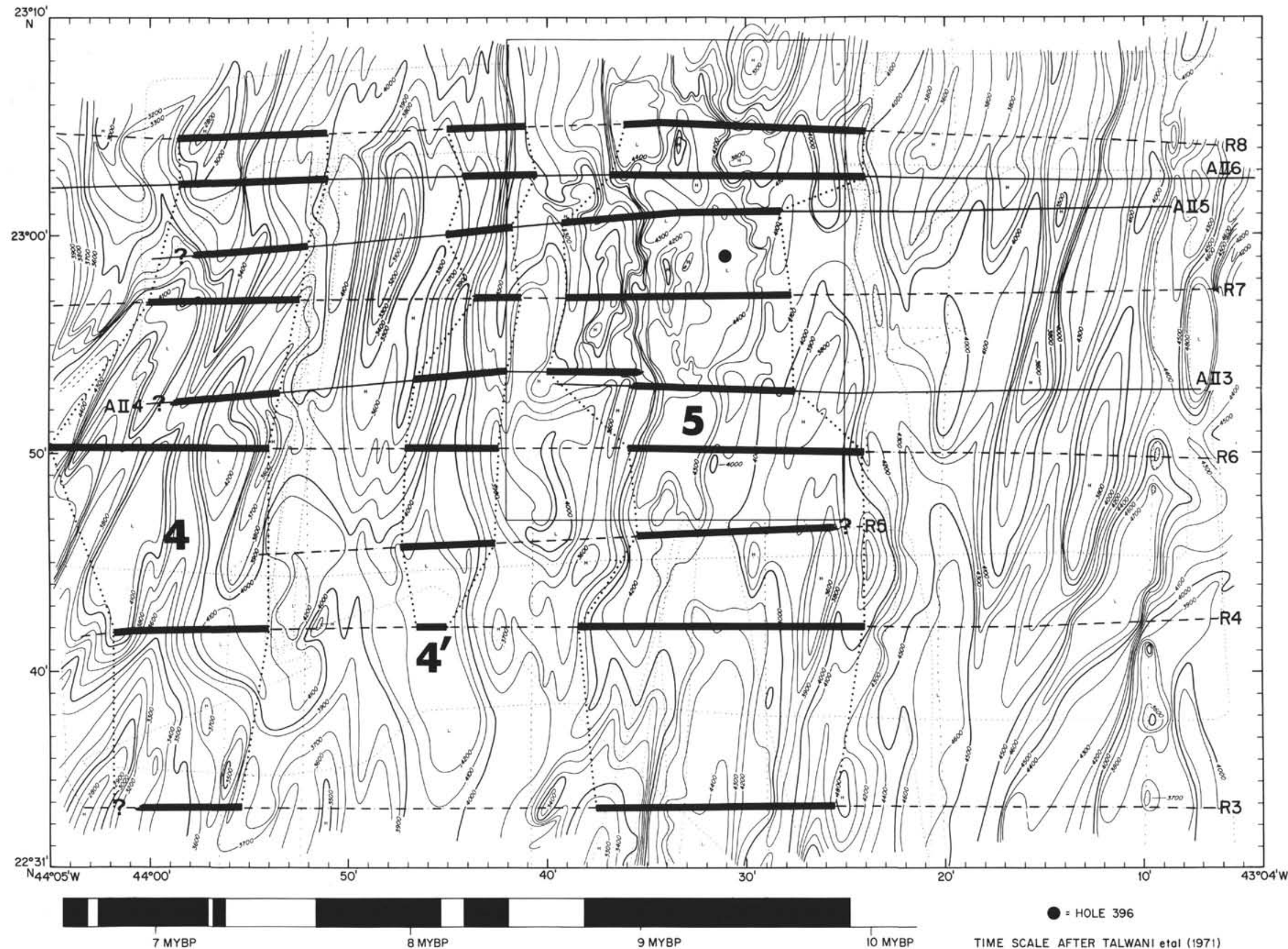

Figure 8. Simplified representation of the calculated magnetization distributions shown in Figure $7(\mathrm{c})$. The solid black lines approximate areas of predominantly positively magnetized crust. The reversal time scale of Talwani et al. (1971) is shown for comparison: a half-spreading rate of 20 mm/year was assumed. 


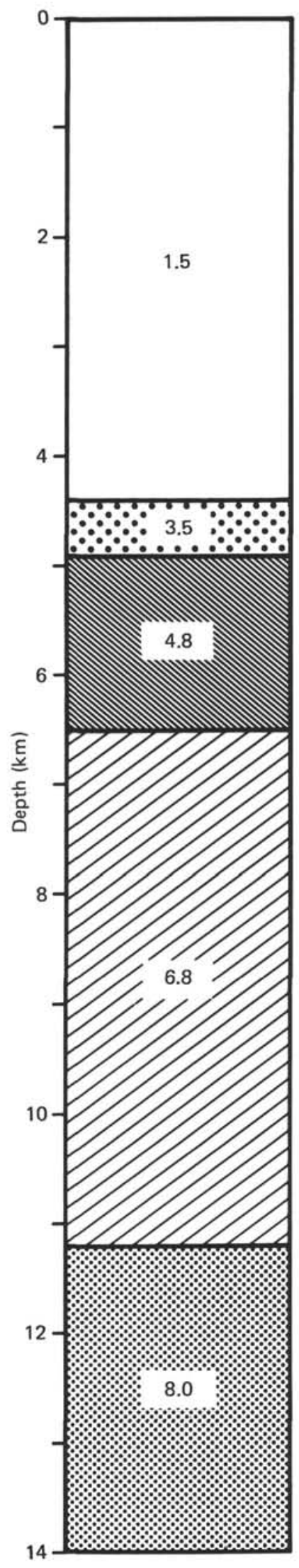

Figure 9. Average crustal section along Five Trough from seismic refraction (Barrett and Purdy, this volume). Velocities in $\mathrm{km} / \mathrm{sec}^{-1}$. 